Proceedings of the New Zealand Grassland Association 47: 187-190 (1986)

\title{
THE ELIMINATION AND REPLACEMENT OF WILD TALL FESCUE IN NORTHLAND DAIRY PASTURES
}

\author{
C.B. GLASSEY and J.B. READE \\ NZ Dairy Board Consulting Office, \\ Whangarei and Dargaville.
}

\begin{abstract}
Wild Tall Fescue can be eliminated from Northland dairy pastures. In this paper the principles and methods for eliminating wild tall fescue are discussed. These are based on observations made to us by dairy farmers, farm advisors and earlier experiences described in farming publications. Emphasis placed on a methodical approach, preparation and having an intensive follow-up programme. Reasons for failure of control programmes are discussed.

Keywords: Wild Tall Fescue, elimination of, cultivation, mowing, herbicides, seed viability, re-infestation.
\end{abstract}

\section{INTRODUCTION}

Wild Tall Fescue (Festuca arundinacea, Schreb.) is a significant weed on many Northland dairy farms. As well as being associated with toxic syndromes in cattle (Dunn 1985, Kearns in press.), the low palatability of the plant complicates pasture management to the point that infested areas contribute little to overall farm production. In addition to lost production opportunities there is a considerable cost to farmers in time and money spent on eradicating tall fescue from pastures. Our concern is that not all the time and money spent on tall fescue control has been well directed. Some farmers have successfully eradicated tall fescue from their farms. Others have tried and either failed to kill existing plants, or suffered from re-infestation, and are frequently of the opinion that wild tall fescue cannot be eradicated from their pastures.

This paper attempts to bring together some of the principles of successful elimination of wild tall fescue from dairy pastures in Northland. The eradication of tall fescue from pastures in the Bay of Plenty, Hauraki Plains and Northland has previously been discussed by Taylor 1938, Saxby 1949, Banfield 1953, and Oliver 1968. Recent developments in effective herbicide control and the direct drilling of new pasture species add to the information discussed in previous papers.

\section{METHOD}

In order to clarify the principle of tall fescue eradication we canvassed the opinion of twelve people, (four Northland dairy farmers, two New Zealand Dairy Board Consulting Officers, three M.A.F. Farm Advisory Officers, two Technical Sales Representatives from chemical companies and one DSIR Scientist) with some knowledge in this field and asked the following questions:-

1. Whether or not they believed that tall fescue could be successfully eradicated from Northland dairy pastures? 7

2. What they considered to be the main principles of eradication.

3. Why they felt some farmers were attempting but failing to eradicate wild tall fescue from their pastures?

\section{RESULTS AND DISCUSSION}

Question 1 - Can tall fescue be eradicated from Northland dairy farms?

All answered "yes" to this one. This is despite the view that has been expressed to us by some dairy farmers that it is not possible to eradicate or control tall fescue. 
Question 2 What are the main principles of eredication of tall fescue?

The replies indicated five major principles for eradication of wild tall fescue. These are: planning, modification of the environment, eradication of existing plants and the elimination of the viable seed in the soil, follow up treatments to suppress seedling regrowth and eliminating sources of re-infestation.

\section{Planning}

There is a need to adopt a long-term methodical approach for successful eradication. The planning of time, labour and cash resources is required before an eradication programme should be started. Committing money to spraying and re-grassing large areas of pasture all at once is of limited value if labour is not available for follow-up control of seedling regrowth, and if sources of seed re-infestation on the farm are not eliminated as well. Employing additional labour may be necessary for a follow-up programme, as this will be in the already busy spring period, prior to the tall fescue plant seeding.

\section{Modification of the Pasture Environment}

Before commencing an eradication programme the question should be asked, "Why is the tall fescue plant present in the pasture?' The simple answer is that the fescue plant has become established due to a lack of competition from other grasses, its tolerance of a wide range of environments (Langer and Hill, 1982), its low palatability and its prolific seeding.

Under conditions favouring the establishment of perennial ryegrass pastures, tall fescue is markedly inferior in germination and establishment to ryegrasses but under drier autumn conditions wild tall fescue can establish well compared to bred conditions of tall fescue and possibly even to ryegrass. (Brock et. al., 1982). If tall fescue is to become established it will be because of poor growth of usually, competitive species. Tall fescue is often associated with poorly drained land, yet it is moderately drought tolerant. Once established tall fescue has an extensive and deep root system (Langer 1973), and appears to be tolerant of both poor drainage and drought. Therefore it has some advantages over companion grass species in poorly drained ares such as peat soils.

For successful eradication, the growing environment will need to be modified to favour the establishment of a highly competitive ryegrass based sward. Drainage and fertility will most probably need to be improved so that the growth of desirable species is not suppressed. Poor grazing management such as pugging in wet soil conditions will contribute to tall fescue infestation and should be avoided if re-infestation is to be prevented (Oliver 1968).

\section{Eradication of Existing Plants and Viable Seed in the Soil}

Cultivation: Saxby (1949) and many farmers report effective kills of tall fescue plants from large scale cultivation such as deep ploughing or rotary hoeing. Cultivation in the spring is usually followed by a summer crop with reworking in the autumn to sow new pasture. Some farmers (and some of our observers) prefer two years of cropping (summer-winter-summer) before autumn resowing. A summer fallow (or crop) was recommended by Banfield (1953) observing farmers controlling tall fescue on the Hauraki Plains. This allows seed in the ground to germinate and be killed by the autumn cultivation and will reduce the quantity of viable seed in the top $10 \mathrm{~cm}$ of soil. Where a summer crop is grown some form of control of tall fescue in the crop will be required to prevent plants seeding in the crop. In veiw of the fact that the survival period of tall fescue seed in the soil is short and practically no seed reserves remain one year after seed deposition in the soil. Hyde (1958), two seasons of cropping or summer fallows seem excessive. 
Full cultivation and summer cropping is not practical in some situations, is increasingly expensive and an eradication programme will be slow if considerable areas of the farm are infested.

Herbicide Cultivation Combination: Because of shallow top soils in many parts of Northland, deep ploughing to completely bury fescue plants is not practical. Farmers on these soils combine an initial blanket herbicide spray, (e.g. 4 litres/ha of Roundup), followed by surface cultivtion in the spring to kill existing tall fescue. This is followed by a summer crop and then a second light spray and cultiviation in the autumn prior to resowing. While summer crop establishment through direct drilling gives variable results, good pasture establishment in the autumn has been achieved using this method.

Herbicide Only: Some farmers have achieved good results from a heavy blanket spray of herbicide in the autumn, (e.g. 4 litres/ha of Roundup) with new pasture being direct drilled into the settling trash two weeks later. The trash present acts as a mulch suppressing fescue seedlings with only the new ryegrass-white clover seedlings establishing in the exposed drill lines. Excessive trash may have to be removed to avoid obstruction of the drilling process.

The success of this method is very dependent on adequate preparation of the tall fescue population for a good herbicide kill. Large clumpy plants should be cut with a silorator and the trash removed in the spring before spraying. The fescue should then be mown regularly to keep plants short, open and to prevent further seeding. This mowing has three benefits in that it:

1. Prevents seeding so that no new seed enters the ground in the year prior to re-grassing.

2. Reduces the tall fescue population by damaging the crowns of plants Oliver (1968).

3. Allows a more complete coverage of herbicide resulting in a better kill. Plants to be sprayed should be $5-8 \mathrm{~cm}$ of green leaf and must not be covered with trash from previous slashings or stock manure from recent grazing.

Follow-Up Treatment on Seedling Re-Growth

Achievement of complete eradication in a new pasture is very rare, and seedling regrowth may occur particularly through new seed arriving from outside pastures. Follow-up spot spraying is a necessity to prevent tall fescue establishing and seeding.

\section{Eliminate Sources of $\mathrm{R}$ e-Infestation}

Fencelines and drains surrounding new pastures must be kept free of tall fescue by annual spot spraying programmes. Seed transfer by stock from an infected to a clear area could well occur under a rotational grazing system. Where cultivation or mowing is not possible spot-spraying should be carried out annually prior to the grass seeding, and alternative grass seed sown in the gap remaining. Check equipment to ensure nozzle discharges are overlapping so strips are not missed. Spraying half the herbicide rates both ways up and across the paddock ensures good coverage. All herbicide should contact green growing fescue leaf. Excessive trash and animal manure may prevent this.

\section{Poor Pasture $M$ anagement}

Tall fescue has a very slow seedling growth (Brock, 1983) and will be discouraged from establishment by grazing management normally used for establishing new pastures. Pugging the new pasture in wet soil conditions will also create a potential environment for re-infestation of the pasture (Oliver 1968).

\section{SUM MARY}

Eradication of tall fescue from dairy pasture requires a methodical planned approach. Success is dependent on: 
1. Killing existing plants thoroughly

2. Eliminating the population of viable seed in the top $10 \mathrm{~cm}$ of soil by: (a) Cultivation, germination and burial (b) Mowing and keeping the grass vegetative in the year prior to re-grassing.

3. Modifying the environment in favour of the establishment of ryegrass-white clover pastures, through improved drainage, fertility, or grazing management. If this Is not done, then the area where eradication is being attempted may be better growing improved tall fescue varities adapted to that environment and more palatable to stock such as "Grasslands Peat" or "5170" tall fescue (Anderson et. al., 1982).

4. Establishing a vigorous ryegrass-white clover sward and applying intensive grazing management aimed at its establishment, and discouraging any tall fescue seedlings that may be present.

5. Control potential sources of seed re-infestation. If these cannot be controlled then remain vigilant for seedlings establishing on clean pasture and have an annual sport spraying programme.

It is apparent to us that successful eradication is not just a matter of choosing the right technique or herbicide. It requires a methodical approach and must be integrated with overall pasture and stock management. On farms where the principles of good grazing management are followed eradication can be achieved and the benefits of establishing new pasture species obtained.

\section{ACKNOWLEDGEMÉNTS}

Comments received from the dairy farmers we approached and our fellow farm advisors (M.A.F., N.Z. Dairy Board and Technical Sales Representatives) helped us clarify a number of issues presented in this paper.

\section{REFERENCES}

Anderson, B.; Brock, J.L.; Boyd, A.F.; Harns, A.J.; Ryan, D.L. 1982. N.Z. J exp Agric, 10. 275.280. Banfield, G.L. 1953. N.Z.J. Agric, 87: 433-436

Brock, J.L. 1983. Proc N.Z. Grassid Ass., 44: 7480

Brock, J.L.; Anderson, L.B.; Lancashire, J.A. 1982. N.Z. J exp Agric 10: 285-289.

Dunn, H. 1985. N.Z. Dairy Exporter 60 No. 7: 25.

Hyde, E.O.C. 1958. Dairyfarming Annual, Massey University, 1958, 149152.

Kearns, M.P. 1985. Proc. N.Z. Grassld Ass., 47: 183-186.

Langer, R.H.M. 1973. In 'Pastures and Pasture Plants' ed. R.H.M. Langer p 77-78

Langer, R.H.M.; Hill G.D. 1982. Agriculture Plants.

Oliver, J.R. 1968. N.Z. J. Agric. J16:46-49

Saxby, S.H. 1949. Ibid. 78: 8-10

Taylor, C.R. 1938. Ibid. 56: 220221. 